\title{
THE EFFECT OF FINANCIAL LEVERAGE TO THE PROFITABILITY AT SUB- SECTORS OF FOOD AND BEVERAGE COMPANIES LISTED ON INDONESIA STOCK EXCHANGE IN 2010-2014
}

\author{
R. Ratna Meisa Dai dan Marsa Khalida Nurahmi \\ Department of Business Administration Science \\ Faculty Social and Political Science University of Padjadjaran \\ Email:lexsa_dai@yahoo.com
}

\begin{abstract}
This study examined the effect of financial leverage to the profitability at Sub-Sectors of Food and Beverage Companies listed on Indonesia Stock Exchange in 2010 - 2014 simultaneously and partially. Financial leverage seen from debt ratio and debt to equity ratio, then profitabilitas seen from return on equity.

The result of the study revealed debt ratio and debt to equity ratio affected the profitability when it simultaneous. However, when it partial debt ratio did not affect the profitability positively, while debt to equity ratio affected the profitability positively.
\end{abstract}

Keywords : financial leverage, debt ratio, debt to equity ratio, profitability, return on equity.

\section{PENGARUH FINANCIAL LEVERAGE TERHADAP PROFITABILITAS PADA PERUSAHAAN SUB SEKTOR MAKANAN DAN MINUMAN YANG TERDAFTAR DI BURSA EFEK INDONESIA PERIODE 2010-2014}

\begin{abstract}
ABSTRAK
Penelitian ini bertujuan untuk mengetahui pengaruh financial levarage terhadap profitabilitas pada perusahaan sub sektor makanan dan minuman yang terdaftar di Bursa Efek Indonesia periode 20102014 baik secara simultan maupun secara parsial. Financial leverage dapat dilihat melalui debt ratio dan debt to equity ratio, sedangkan profitabilitas dapat dilihat melalui return on equity.

Hasil penelitian menunjukkan bahwa secara simultan kedua variabel independen, yaitu debt ratio dan debt to equity ratio secara bersama-sama berpengaruh terhadap profitabilitas. Untuk pengaruh secara parsial, hasil penelitian menunjukkan bahwa debt ratio tidak berpengaruh positif terhadap profitabilitas, sedangkan debt to equity ratio berpengaruh positif terhadap profitabilitas.
\end{abstract}

Kata kunci : financial leverage, debt ratio, debt to equity ratio, profitabilitas, return on equity. 


\section{PENDAHULUAN}

Saat ini industri makanan dan minuman di Indonesia sedang mengalami perkembangan yang pesat. Industri makanan dan minuman mendapat peluang yang besar untuk terus tumbuh dibandingkan dengan industri kreatif lainnya. Industri makanan dan minuman menjadi penyumbang terbesar bagi Produk Domestik Bruto (PDB) diantara sektor lainnya, yaitu sebesar 8,7\% (jurnal Industry Update Bank Mandiri). Hal ini mengakibatkan trend investasi untuk industri makanan minuman mengalami kenaikan.

Menghadapi situasi dan kondisi yang dihadapi perusahaan saat ini setiap perusahaan harus mampu melakukan pengelolaan yang baik pada setiap kegiatan-kegiatan usahanya, terutama pada fungsi keuangan untuk meningkatkan volume penjuaan dan tingkat keuntungan. Perusahaan dalam mengelola fungsi keuangan salah satu unsur yang harus diperhatikan adalah seberapa besar kemampuan perusahaan dalam menghasilkan laba yang optimal bagi pemilik perusahaan atau pemegang saham. Laba merupakan penghasilan dari kegiatan perusahaan yang sangat penting bagi kelangsungan hidup suatu perusahaan. Kelangsungan hidup perusahaan akan bertahan jika perusahaan mendapatkan keuntungan dan meningkatkan kesejahteraan.

Penilaian tingkat keuntungan perusahaan diperoleh dari informasi akuntansi dalam bentuk rasio keuangan, yaitu rasio profitabilitas. Informasi ini sebagai acuan untuk seorang investor menganalisis performa baik atau buruknya bisnis yang akan di investasikan. Untuk mengukur besar kecilnya laba yang dihasilkan oleh perusahaan, digunakan rasio profitabilitas. Menurut Kasmir (2011:96), rasio profitabilitas adalah rasio untuk menilai kemampuan perusahaan dalam mencari keuntungan. Rasio yang digunakan dalam penelitian ini adalah Return on Equity. Rasio ini dapat memberikan ukuran tingkat produktivitas perusahaan. Hal ini ditunjukkan oleh laba yang diperoleh dari produktivitas seluruh dana yang digunakan baik modal pinjaman maupun modal sendiri.

Setiap perusahaan industri makanan dan minuman besar di Indonesia memerlukan modal yang besar pula untuk menjalankan usahanya tiap hari, seperti untuk membeli bahan baku, biaya transportasi pengiriman barang, upah buruh dan lain sebagainya, di mana dana yang telah dikeluarkan dapat kembali lagi dalam perusahaan melalui hasil dari penjualan barang yang di produksi. Maka dari itu kebanyakan perusahaan di Indonesia memakai modal pinjaman/modal dari hutang dari pihak lain, baik dari investor atau meminjam dari bank. Pengelolaan modal dari pinjaman sangat penting dan harus efektif, karena perusahaan wajib mengembalikan modal pinjaman itu dengan cara membayar secara berkala. Bila modal pinjaman itu tidak bisa dikembalikan oleh perusahaan terkait maka perusahaan itu akan disita oleh pihak peminjam dana. Rasio hutang yang digunakan adalah rasio financial leverage. Pada penelitian ini, rasio financial leverage diwakili oleh Debt Ratio dan Debt Equity Ratio. Rasio ini dapat mengukur seberapa jauh perusahaan mampu memenuhi kewajiban keuangannya. dan penurunan pada setiap tahun yang mempengaruhi total hutangnya.

Financial leverage merupakan kemapuan perusahaan dalam mengelola pendanaan yang berasal dari modal pinjaman, sehingga perusahaan dapat beroperasi, berinvestasi, dan mengembangkan usahanya. Pada dasarnya, semakin tinggi hutang perusahaan, maka semakin besar risiko yang dimiliki perusahaan, namun dari tingkat pengembaliannya (laba) akan semakin besar pula. Akan tetapi terdapat perbedaan dengan teori dasar, perusahaan yang memiliki leverage tinggi akan menghadapi kesulitan keuangan dalam menyelesaikan utangnya. Rasio hutang yang tinggi memaksa perusahaan harus membayar kewajibannya dan mengurangi tingkat pengembalian modal awalnya. Rasio hutang yang rendah dapat meningkatkan profitabilitas perusahaan, sehingga tingkat pengembalian modal semakin besar. 


\section{TINJAUAN PUSTAKA}

\section{Financial Leverage}

Menurut Brigham dan Houston (2009:425), "Financial leverage is the extent to which fixedincome securities (debt and preferred stock) are used in a firms's capital structure". Artinya financial leverage ialah tingkat sampai sejauh mana sekuritas dengan laba tetap (hutang dan saham preferen) digunakan dalam struktur modal dalam sebuah perusahaan. Financial leverage dilihat dari perusahaan menggunakan pendanaan melalui utangnya.

\section{Pengukuran Financial Leverage}

Financial leverage sering kali diukur dengan rasio-rasio yang sederhana seperti: debt ratio, debt equity ratio, time-interest earned, atau rasio antara pinjaman jangka panjang dengan saham preferen dibandingkan dengan total kapitalisasi perusahaan (Syamsuddin, 2011:119). Adapun pengukuran financial leverage dalam penelitian ini diwakili dengan debt ratio (DR) dan debt equity ratio (DER). Masing-masing rasio tersebut menujukkan hubungan antara dana dari mana beban-beban finansial harus dibayar dengan modal yang ditanamkan di dalam perusahaan. Sebagian besar analisis keuangan mengitung rasio-rasio ini dalam usaha membayar kewajibankewajiban finansial yang bersifat tetap.

\section{Debt Ratio}

Debt ratio merupakan rasio yang mengukur berapa besar aktiva perusahaan yang dibiayai oleh kreditur. Semakin tinggi debt ratio, maka semakin besar jumlah modal pinjaman yang digunakan dalam menghasilkan keuntungan bagi perusahaan. Ratio ini dihitung sebagai berikut:

$$
\text { Debt Ratio }=\frac{\text { Total Liabilities }}{\text { Total Assets }}
$$

2. Debt Equity Ratio

Debt to Equity Ratio (DER) merupakan rasio yang menunjukan perbandingan antara hutang dengan modal sendiri. Berdasarkan pendapat di atas, Debt to Equity Ratio (DER) digunakan untuk mengukur kemampuan perusahaan dalam menutup sebagian atau seluruh hutang-hutangnya baik jangka panjang maupun jangka pendek dengan dana yang berasal dari total modal dibandingkan besarnya hutang. Adapun perhitungan ratio ini adalah sebagai berikut :

$$
\text { Debt Equity Ratio }=\frac{\text { Total Debt }}{\text { Stockholders Equity }}
$$

\section{Pengertian Profitabilitas}

Menurut Van Horne dan Wachowicz (2008:148), menyatakan "Profitability is the ability to generate profits for a certain period with rhe use of productive assets or capital". Artinya, profitabilitas merupakan kemampuan menghasilkan laba selama periode tertentu dengan menggunakan aktiva yang produktif atau modal, baik modal secara keseluruhan maupun modal sendiri.

\section{Jenis-jenis Profitabilitas}

Menurut Van Horne dan Wachowicz dalam terjemahan Fitriasari (2013:180) rasio profitabilitas terdiri dari dua jenis, diantaranya adalah:

1. Rasio dalam kaitannya dengan penjualan. Rasio ini terdiri dari:
a. Gross Profit Margin (GPM)
b. Net Profit Margin (NPM)

2. Rasio dalam kaitannya dengan investasi. Rasio ini terdiri dari:

a. Return On Assets (ROA)

\section{Return On Equity}

Rasio ini menunjukkan kemampuan menghasilkan laba pada nilai buku investasi pemegang saham dan seringkali digunakan dalam membandingkan dua atau lebih perusahaan industri. Pengembalian ekuitas yang tinggi sering kali merefleksikan penerimaan perusahaan atau kesempatan investasi yang kuat dan manajemen biaya yang efektif.

$$
R O E=\frac{\text { Laba bersih setelah pajak }}{\text { Ekuitas pemegang saham }}
$$




\section{METODE PENELITIAN}

\section{Populasi dan Sampel}

Dalam penelitian ini yang menjadi populasi adalah perusahaan sub sektor makanan dan minuman yang terdaftar di BEI periode 20102014. Berdasarkan kriteria pemilihan populasi tersebut, terdapat 12 perusahaan sub sektor makanan dan minuman yang terdaftar di Bursa Efek Indonesia pada tahun 2010-2014 yang memenuhi kriteria. Teknik penarikan sampel menggunakan sampling jenuh dimana seluruh anggota dari populasi dijadikan sampel, yaitu sebanyak 12 perusahaan food and beverage yang terdaftar di Bursa Efek Indonesia pada tahun 2010-2014.

\section{Teknik Analisis Data}

Teknik analisis yang digunakan pada penelitian ini adalah analisis regresi linear berganda (multiple regression analysis) sedangkan pengolahan datanya menggunakan software Eviews 8. Menurut Sugiyono, (2013:277), analisis regresi digunakan oleh peneliti, bila peneliti bermaksud meramalkan bagaimana keadaan (naik turunnya) variabel dependen, bila dua atau lebih variabel independen sebagai faktor prediktor dimanipulasi (dinaik turunkan nilainya).

\section{Analisis Data Panel}

Penelitian ini menggunakan model ekonomerika berupa analisis data panel dengan menggunakan software Eviews 8. Analisis dengan menggunakan panel data adalah kombinasi dari data time series dan cross section. Dengan mengakomodasi dalam model informasi baik yang terkait variabel-variabel cross section maupun time series, data panel secara substansial mampu menurunkan masalah omitted variables, model yang mengabaikan variabel yang relevan (Ajija et.,al, 2011).

\section{Uji Data Panel}

Untuk menguji validitas nilai determinasi berganda tersebut kita harus menguji pula regresi data panel ini. Tujuannya adalah untuk membandingkan dan membuktikan keakuratan data dan juga validitas data tersebut. Pemilihan metode estimasi regresi data panel dilakukan melalui dua tahap, diantaranya:

\section{Chow Test}

Merupakan pengujian untuk memilih apakah model yang digunakan adalah model common effect atau model fixed effect. Hipotesis dalam pengujian chow adalah:

\section{Ho: Common Effect Model \\ H1: Fixed Effect Model}

\section{Haussman Test}

Merupakan pengujian untuk memilih apakah model yang digunakan adalah model fixed effect atau model random effect. Hipotesis dalam pengujian chow adalah:

Ho: Random Effect Model

H1: Fixed Effect Model

\section{Uji Asumsi Klasik}

Pada penelitian ini, uji asumsi klasik dilakukan untuk memastikan bahwa sampel yang diteliti terhindar dari multikolinearitas, autokorelasi, dan heteroskedastisitas. Uji multikolinearitas bertujuan untuk menguji apakah model regresi ditemukan adanya korelasi antar variabel independen. Uji autokorelasi bertujuan menguji apakah dalam model regresi linear ada korelasi antara kesalahan pengganggu pada periode $\mathrm{t}$ dengan kesalahan pengganggu pada periode t-1 (sebelumnya). Uji heteroskedastisitas bertujuan menguji apakah dalam model regresi terjadi ketidaksamaan variance dari residual satu pengamatan ke pengamatan yang lain.

\section{Analisis Regresi Data Panel}

Analisis regresi digunakan untuk mengukur kekuatan hubungan antara dua variabel atau lebih. Analisis ini juga dapat menunjukkan arah hubungan antara variabel dependen dan variabel independen. Dalam penelitian ini, analisis regresi linear berganda digunakan untuk mengetahui ada tidaknya pengaruh Financial Leverage (Debt Ratio dan Debt to Equity Ratio) terhadap Profitabilitas (Return on Equity) perusahaan Consumer Goods yang terdaftar di BEI. Persamaan regresi yang digunakan dalam penelitian ini adalah: 


$$
\mathrm{ROE}=\alpha+\beta 1 \mathrm{DR}+\beta 2 \mathrm{DER}+\varepsilon i t
$$

Keterangan:

$\mathrm{ROE}=$ Return on Equity

$A \quad=$ Kostanta

$\beta 1, \beta 2=$ Koefisien regresi

$\mathrm{DR}=$ Debt Ratio

DER = Debt to Equity Ratio

eit $=$ Error Disturbances

\section{Koefisien Determinasi}

Koefisien determinasi $\left(\mathrm{R}^{2}\right)$ merupakan alat ukur seberapa jauh kemampuan model dalam menerangkan variasi variabel dependen. Nilai $\mathrm{R}^{2}$ yang kecil berarti kemampuan variabel-variabel independen dalam menjelaskan variasi-variabel dependen amat terbatas. Nilai yang mendekati satu berarti variabel-variabel independen memberikan hampir semua informasi yang dibutuhkan untuk memprediksi variasi variabel dependen.

\section{Uji Hipotesis}

\section{Uji Signifikansi Simultan (Uji Statistik F)}

Uji statistik $F$ berguna untuk menunjukkan apakah semua variabel independen yang dimasukkan dalam model mempunyai pengaruh secara bersama-sama terhadap variabel dependen. Hipotesis yang akan diuji adalah:

$$
\text { Ho : } \beta_{1}=\beta_{2}=\beta_{3}=\ldots=\beta_{\mathrm{n}}=0
$$

Artinya, semua variabel independen secara simultan tidak memiliki pengaruh yang signifikan terhadap variabel dependen.

$$
\text { Ha : } \beta_{1} \neq \beta_{2} \neq \beta_{3} \neq \ldots \neq \beta_{\mathrm{n}} \neq 0
$$

Artinya, semua variabel independen secara simultan memiliki pengaruh yang signifikan terhadap variabel dependen.

Pengujian hipotesis menggunakan uji statistik $F$ dilakukan dengan cara membandingkan nilai $F$ hasil perhitungan dengan nilai $\mathrm{F}$ menurut tabel. Kriteria pengambilan keputusannya adalah sebagai berikut: (1) Apabila nilai F hitung > F tabel, maka Ho ditolak dan menerima Ha; (2) Apabila nilai $\mathrm{F}$ hitung $\leq \mathrm{F}$ tabel, maka $\mathrm{Ho}$ diterima dan menolak Ha.

\section{Uji Signifikansi Parsial (Uji Statistik t)}

Uji statistik $t$ menunjukkan seberapa jauh pengaruh satu variabel independen secara individual dalam menerangkan variasi variabel dependen. Artinya, apakah suatu variabel independen bukan merupakan penjelas yang signifikan terhadap variabel dependen atau tidak. Bentuk hipotesis dari Uji statistik t ini adalah:

a. $\mathrm{Ho}_{1}: \beta_{1} \leq 0$

Artinya, variabel debt ratio tidak berpengaruh positif secara parsial terhadap profitabilitas.

$\mathrm{Ha}_{1}: \beta_{1}>0$

Artinya, variabel debt ratio berpengaruh positif secara parsial terhadap profitabilitas.

b. $\mathrm{Ho}_{2}: \beta_{2} \geq 0$

Artinya, variabel debt to equity ratio tidak berpengaruh positif secara parsial terhadap profitabilitas.

$\mathrm{Ha}_{2}: \beta_{2}<0$

Artinya, variabel investment opportunity set berpengaruh positif secara parsial terhadap profitabilitas.

Pengujian hipotesis uji statistik $t$, dilakukan dengan cara membandingkan nilai $\mathrm{t}$ hasil perhitungan dengan nilai $t$ menurut tabel. Kriteria pengambilan keputusannya sebagai berikut: (1) Apabila $\mathrm{t}$ hitung $>\mathrm{t}$ tabel, maka Ho ditolak dan menerima Ha. Artinya, suatu variabel independen berpengaruh terhadap variabel dependen; (2) Apabila $\mathrm{t}$ hitung $\leq \mathrm{t}$ tabel, maka Ho diterima dan menolak Ha. Artinya, suatu variabel independen tidak berpengaruh terhadap variabel dependen. 


\section{HASIL DAN PEMBAHASAN}

\section{Uji Data Panel}

\section{Chow Test}

Tabel 1

Hasil Pengujian Chow Test

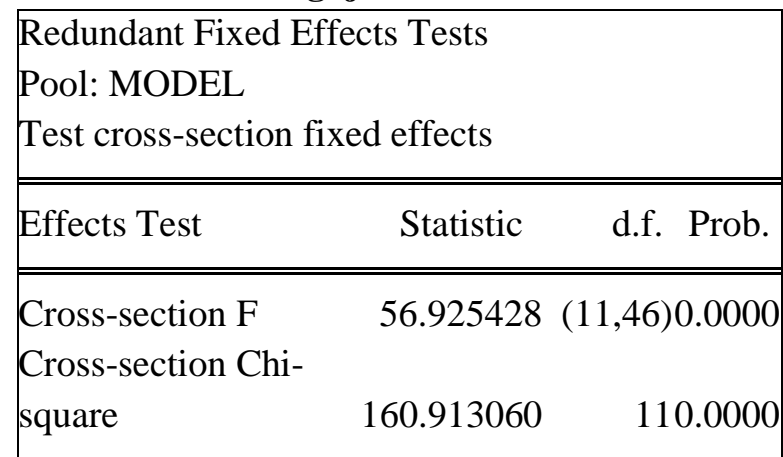

Sumber : Ouput Eviews 8.0 (data diolah, 2016)

Berdasarkan tabel 1 di atas, dapat kita lihat bahwa nilai Cross-Section $\mathrm{F}<0,05$ sehingga Ho ditolak dan model Fixed Effect dipilih sebagai model terbaik untuk digunakan dalam regresi data panel.

\section{Haussman Test}

Tabel 2

Hasil Pengujian Hausman Test

Correlated Random Effects - Hausman

Test

Pool: MODEL

Test cross-section random effects

\begin{tabular}{|lcr|}
\hline \hline \multirow{2}{*}{ Test Summary } & \multicolumn{2}{c|}{ Chi-Sq. Chi-Sq. } \\
& Statistic & d.f. Prob. \\
\hline \hline Cross-section random & 14.581727 & 20.0007 \\
\hline \hline
\end{tabular}

Sumber : Ouput Eviews 8.0 (data diolah, 2016)

Berdasarkan tabel 2 di atas, dapat kita lihat bahwa nilai Cross-Section Random < 0,05 sehingga Ho ditolak dan model Fixed Effect dipilih sebagai model terbaik untuk digunakan dalam regresi data panel.

\section{Uji Asumsi Klasik \\ Uji Asumsi Normalitas}

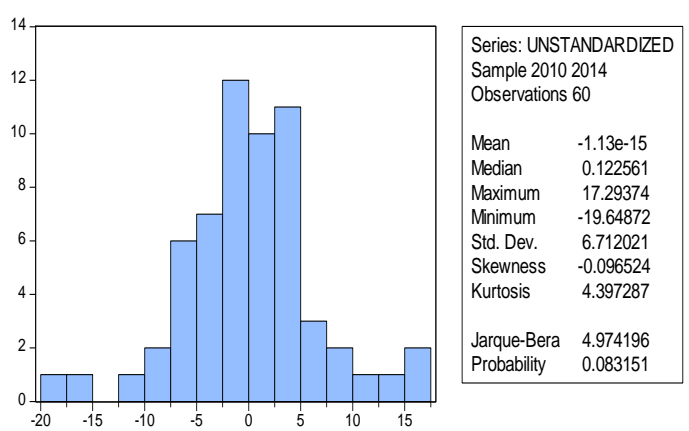

Sumber : Ouput Eviews 8.0 (data diolah, 2016)

\section{Gambar 1}

\section{Hasil Uji Normalitas Jarque-Bera}

Pada gambar 1 dapat dilihat nilai probability JB $(0,083)$ yang diperoleh dari uji Jarque-Bera untuk data residual lebih besar dari 0,05. Karena nilai probabilitas pada uji Jarque-Bera model lebih besar dari tingkat kekeliruan 5\% (0.05), maka disimpulkan bahwa model regresi berdistribusi normal.

\section{Uji Asumsi Heteroskedastisitas}

Tabel 3

Hasil Uji Heteroskedastisitas

White Heteroskedasticity Test:

\begin{tabular}{lccc}
\hline \hline $\begin{array}{l}\text { F-statistic } \\
\text { Obs*R- } \\
\text { squared }\end{array}$ & $\begin{array}{c}\text { 7.321140 Square(3) } \\
\text { Prob. Chi- }\end{array}$ & 0.062337 \\
\hline
\end{tabular}

Sumber : Ouput Eviews 8.0 (data diolah, 2016)

Hasil perbandingan nilai Obs*R-squared dengan $\chi^{2}$ tabel seperti disajikan pada tabel 3 memberikan suatu indikasi bahwa residual (error) yang muncul dari persamaan regresi mempunyai varians yang homogen (tidak terjadi heteroskedastisitas). Hal ini ditunjukkan oleh nilai Obs*R-squared yang lebih kecil dari $\chi^{2}$ tabel. 
Uji Asumsi Autokorelasi

Tabel 4

Hasil Perhitungan Uji Autokorelasi

Mean

R-squared $\quad 0.901883$ dependent var 27.57218

Adjusted R-

S.D.

squared

S.E. of

regression

0.874154dependent var 17.34441

Sum squared

7.004546resid

Durbin-

F-statistic 32.52517Watson stat

2256.929

Prob(F-

statistic) $\quad 0.000000$

Sumber : Ouput Eviews 8.0 (data diolah, 2016)

Setelah menggunakan software Eviews 8.0 diperoleh nilai Durbin-Watson Test $=1,628788$. mengacu pada tabel Durbin-Watson, dengan $\mathrm{n}=60$ dan $\mathrm{k}=2$, maka diperoleh $\mathrm{dL}=1,5244$ dan $\mathrm{dU}=1,6518$. Sesuai dengan kriteria uji autokorelasi di atas, maka dapat disimpulkan model tidak terjadi autokorelasi karena dapat dilihat bahwa (dU) $1,6518<(\mathrm{dW}) 1,828788<(4-$ dU) 2,3482 .

\section{Uji Asumsi Multikolinieritas}

Tabel 5

Hasil Pengujian Asumsi Multikolinieritas

\begin{tabular}{|c|c|c|}
\hline $\begin{array}{c}\text { Variabel } \\
\text { Independen }\end{array}$ & R-square & VIF \\
\hline DR & 0,869 & 7,634 \\
\hline DER & 0,869 & 7,634 \\
\hline
\end{tabular}

Sumber : Ouput Eviews 8.0 (data diolah, 2016)

Berdasarkan nilai VIF yang diperoleh seperti disajikan pada tabel 5 diatas menunjukkan tidak terdapat multikolinieritas antara Debt Ratio dengan variabel Debt to Equity Ratio, dimana nilai VIF dari variabel kedua variabel independen tersebut masih lebih kecil dari 10.
Analisis Regresi Data Panel

Tabel 6

Hasil Analisis Regresi Linier Berganda

\begin{tabular}{|crrrrr|}
\hline \hline Variable & Coefficient & Std. Error & t-Statistic & Prob. \\
\hline \hline C & 31.90225 & 3.559566 & 8.962397 & 0.0000 \\
DR? & -43.41996 & 18.61955 & -2.331956 & 0.0241 \\
DER? & 13.21052 & 5.635585 & 2.344125 & 0.0234 \\
\hline
\end{tabular}

Sumber : Ouput Eviews 8.0 (data diolah, 2016)

Berdasarkan tabel 6 di atas, maka dapat dirumuskan persamaan regresi taksiran untuk melihat pengaruh financial leverage yang diwakili oleh Debt Ratio dan Debt to Equity Ratio terhadap Profitabilitas (Return on Equity) pada perusahaan sub sektor makanan dan minuman yang terdaftar di Bursa Efek Indonesia tahun 2011-2014 adalah sebagai berikut:

$$
\begin{aligned}
\text { ROE }= & 31.90225-43.41996 \mathrm{DR}+ \\
& \text { 13.21052DER }+ \text { eit }
\end{aligned}
$$

\section{Koefisien Determinasi}

Tabel 7

Hasil Koefisien Determinasi

Cross-section fixed (dummy variables)

\begin{tabular}{lclc}
\hline \hline R-squared & 0.901883 & $\begin{array}{l}\text { Mean } \\
\text { dependent var }\end{array}$ & 27.57218 \\
\cline { 2 - 3 } $\begin{array}{l}\text { Adjusted R- } \\
\text { squared }\end{array}$ & 0.874154 & $\begin{array}{l}\text { S.D. dependent } \\
\text { var }\end{array}$ & 17.34441 \\
$\begin{array}{l}\text { S.E. of } \\
\text { regression }\end{array}$ & 7.004546 & $\begin{array}{l}\text { Sum squared } \\
\text { resid }\end{array}$ & 2256.929 \\
F-statistic & 32.52517 & $\begin{array}{l}\text { Durbin-Watson } \\
\text { stat }\end{array}$ & 1.628788 \\
Prob(F-statistic) & 0.000000 & &
\end{tabular}

Sumber: Ouput Eviews 8.0 (data diolah, 2016)

Berdasarkan tabel 7 dapat dilihat nilai adjusted R-Square sebesar 0,874 atau $87,4 \%$ menunjukkan bahwa financial leverage secara simultan mampu menerangkan perubahan profitabilitas pada perusahaan sub sektor makanan dan minuman yang tercatat di Bursa Efek Indonesia sebesar 87,4 persen. Dengan kata lain financial leverage yang terdiri dari Debt Ratio dan Debt to Equity Ratio secara bersamasama memberikan kontribusi atau pengaruh sebesar 87,4\% terhadap Return on Equity. 
Sisanya pengaruh faktor-faktor lain yang tidak diamati adalah sebesar 12,6\%, merupakan pengaruh faktor lain diluar kedua variabel financal leverage yang tidak diteliti dalam penelitian ini.

\section{Pengujian Hipotesis}

\section{Uji Signifikansi Simultan (Uji Statistik F)}

Berdasarkan tabel 7 diatas, diperoleh nilai Fstatistik sebesar 32,525 dengan nilai probabilitas sebesar $0,0000<0,05$, sedangkan nilai F-tabel dengan $\mathrm{df}_{1}=2$ dan $\mathrm{df}_{2}=57$ adalah sebesar 3,16 . Hal ini menunjukkan bahwa nilai F-stat > F-tabel sehingga menghasilkan kesimpulan $\mathrm{H}_{1}$ diterima. Kesimpulan ini didukung pula dengan nilai probabilitas yang lebih kecil dari alpha $(\alpha=0,05)$ yakni sebesar 0,0000 . Artinya dengan tingkat kekeliruan $5 \%$ dapat disimpulkan bahwa financial leverage yang terdiri dari Debt Ratio dan Debt to Equity Ratio secara simultan berpengaruh terhadap profitabilitas (Return on Equity) pada perusahaan sub sektor makanan dan minuman yang tercatat di Bursa Efek Indonesia periode 2010-2014.

\section{Uji Signifikansi Parsial (Uji Statistik t)}

Tabel 4.6 diatas, dapat terlihat nilai koefisien probabilitas dari masing-masing variabel independen. Nilai t-tabel dengan tingkat signifikansi $5 \%(\alpha=0,05)$ dan degree of freedom (df)=n-k-1=57, n merupakan jumlah sampel yaitu sebanyak 60 sampel dan $\mathrm{k}$ merupakan jumlah variabel independen yaitu sebanyak 2 variabel, maka diperoleh t-tabel sebesar 1,672.

\section{- Pengaruh Debt Ratio Terhadap Return on Equity}

Hipotesis:

Ho. $\beta_{1} \quad$ Debt Ratio tidak berpengaruh signifikan $\leq 0$ : terhadap Return on Equity pada perusahaan sub sektor makanan dan minuman yang tercatat di Bursa Efek Indonesia

Ha. $\beta_{1}$ Debt Ratio berpengaruh signifikan $>0$ : terhadap Return on Equity pada perusahaan sub sektor makanan dan minuman yang tercatat di Bursa Efek Indonesia
Pengujian hipotesis mengenai pengaruh variabel Debt Ratio terhadap Return on Equity menunjukkan t-hitung sebesar 2,331. Nilai tersebut kemudian dibandingkan dengan nilai $\mathrm{t}$ tabel sebesar 1,667. Nilai t-hitung yang lebih besar dari nilai t-tabel dengan nilai signifikansi sebesar $0,0241 \quad(p<0,05)$ menunjukkan bahwa $\mathrm{H}_{1}$ dengan arah nilai koefisien regresi bertanda negatif. Kesimpulan tersebut didukung dengan nilai probabilitas sebesar 0,0241 yang lebih kecil dari nilai $\alpha=0,05$. Artinya, tingkat kesalahan untuk menyatakan bahwa Debt Ratio berpengaruh negatif terhadap Return on Equity sebesar 2,41\% lebih kecil dari tingkat kesalahan yang telah ditetapkan sebesar 0,05. Jadi, dapat disimpulkan bahwa dengan tingkat signifikansi $5 \%$ Debt Ratio berpengaruh negatif secara signifikan terhadap Return on Equity pada perusahaan sub sektor makanan dan minuman yang terdaftar di Bursa Efek Indonesia periode 2010-2014.

\section{- Pengaruh Debt to Equity Ratio Terhadap Return on Equity}

Hipotesis:

Ho. $\beta_{2}$ Debt to Equity Ratio tidak berpengaruh $\leq 0$ : $\quad$ signifikan terhadap Return on Equity pada perusahaan sub sektor makanan dan minuman yang tercatat di Bursa Efek Indonesia

Ha. $\beta_{2}$ Debt to Equity Ratio berpengaruh $>0$ : signifikan terhadap Return on Equity pada perusahaan sub sektor makanan dan minuman yang tercatat di Bursa Efek Indonesia

Pengujian hipotesis mengenai pengaruh variabel Debt to Equity Ratio terhadap Return on Equity menunjukkan t-hitung sebesar 2,344. Nilai tersebut kemudian dibandingkan dengan nilai t-tabel sebesar 1,667. Nilai t-hitung yang lebih besar dari nilai t-tabel dengan nilai signifikansi sebesar $0,0234(\mathrm{p}<0,05)$ serta arah koefisien regresi bertanda positif keputusan yang diambil adalah menerima $\mathrm{H}_{1}$. Kesimpulan tersebut didukung dengan nilai probabilitas sebesar 0,0234 yang lebih kecil dari nilai 
$\alpha=0,05$. Artinya, tingkat kesalahan untuk menyatakan bahwa Debt to Equity Ratio berpengaruh positif secara signifikan terhadap Return on Equity sebesar 2,34\% lebih kecil dari tingkat kesalahan yang telah ditetapkan sebesar 0,05. Jadi, dapat disimpulkan bahwa dengan tingkat signifikansi 5\% Debt Ratio berpengaruh positif secara signifikan terhadap Return on Equity pada perusahaan sub sektor makanan dan minuman yang terdaftar di Bursa Efek Indonesia periode 2010-2014.

\section{Pembahasan Penelitian}

\section{Pengaruh Financial Leverage terhadap Profitabilitas secara Simultan}

Hasil perhitungan dengan menggunakan software Eviews 8 menunjukkan bahwa pada tingkat signifikansi $\alpha=0,05$, nilai F-stat lebih besar dibandingkan dengan nilai tabel dengan tingkat probabilitas lebih kecil dari 0,05, sehingga diputuskan untuk menerima $\mathrm{H}_{1}$. Jadi dapat disimpulkan bahwa financial leverage yang terdiri dari Debt Ratio dan Debt to Equity Ratio secara bersama-sama mempengaruhi variabel profitabilitas pada perusahaan makanan dan minuman yang terdaftar di Bursa Efek Indonesia periode 2010-2014. Financial leverage yang terdiri dari Debt Ratio dan Debt to Equity Ratio menjelaskan variasi profitabilitas (ROE) sebanyak $87,4 \%$ sedangkan $12,8 \%$ lainnya dapat dijelaskan oleh variabel lain.

Penggunaan financial leverage yang semakin besar membawa dampak positif bila pendapatan yang diterima dari penggunaan dana tersebut lebih besar daripada beban keuangan yang dikeluarkan, sedangkan dampak negatifnya penggunaan financial leverage yang semakin besar akan menyebabkan utang semakin besar yang ditanggung perusahaan, yaitu beban tetap atau beban bunganya. Apabila perusahaan tidak memenuhi kewajibannya yang berupa beban bunganya, maka perusahaan akan mengalami kesulitan untuk menjalankan kegiatan usahanya.

Hasil analisis penelitian secara simultan berpengaruh signifikan. Hal ini terjadi karena pada periode hutang yang dimiliki perusahaan sub sektor makanan dan minuman periode 2010-
2014 berada diatas rata-rata industri. Namun ada beberapa perusahaan yang memiliki tingkat hutang yang rendah dalam periode 2010-2014. Tetapi hal tersebut tertutupi oleh perusahaan lainnya yang memiliki hutang yang besar. Namun dalam rasio hutang, perusahaan yang memiliki tingkat hutang yang rendah tersebut merupakan perusahaan dalam kondisi baik, karena perusahaan yang memiliki tingkat hutang yang tinggi dikhawatirkan tidak bisa membayar kewajibannya.

Keadaan financial leverage yang terdiri dari Debt Ratio dan Debt to Equity Ratio pada perusahaan sub sektor makanan dan minuman periode 2010-2014 mengalami fluktuasi. Hal ini disebabkan perusahaan mampu mengatur keuangan yang bisa mendanai perusahaan dengan dana pinjaman atau hutang tanpa mengalami kebangkrutan. Rata-rata perusahaan makanan dan minuman yang melakukan pinjaman dikarenakan krisis global ekonomi yang terjadi di pasar modal yang mengakibatkan bahan baku perusahaan untuk produksi mengalami kenaikan

\section{Pengaruh Debt Ratio secara Parsial terhadap Profitabilitas (Return on Equity) pada Perusahaan Makanan dan Minuman yang terdaftar di Bursa Efek Indonesia periode 2010-2014}

Hasil pengujian hipotesis parsial menunjukkan nilai t-stat untuk variabel Debt Ratio diperoleh sebesar 2,331 dengan nilai probabilitas sebesar 0,0241. Nilai t-stat yang diperoleh lebih besar dari nilai t-tabel sehingga keputusan dalam pengujian hipotesis adalah menerima $\mathrm{H}_{1}$. Kesimpulan tersebut didukung pula dengan nilai probabilitas sebesar 0,0241 yang berarti lebih kecil dari nilai $\alpha=0,05$. Jadi, dapat disimpulkan bahwa pada tingkat signifikansi $95 \%$ Debt Ratio berpengaruh terhadap profitabilitas (Return on Equity) pada perusahaan sub sektor makanan dan minuman yang terdaftar di Bursa Efek Indonesia periode 2010-2014.

Sementara nilai koefisien regresi atas variabel Debt Ratio diperoleh nilai sebesar 43,419. Hal ini menunjukkan bahwa Debt Ratio 
memiliki pengaruh negatif terhadap profitabilitas (Return on Equity). Pengaruh negatif ini berarti, ketika nilai Debt Ratio meningkat satu satuan, maka rasio profitabilitas (Return on Equity) akan menurun sebesar 43,419 satuan. Jadi, semakin tinggi jumlah aktiva perusahaan yang dibiayai oleh hutang (proporsi hutang atas aktiva) maka akan semakin kecil tingkat pengembalian laba yang didapat perusahaan. Hasil penelitian ini sejalan dengan teori yang dikemukakan oleh Mahmud M. Hanafi dan Abdul Halim (2003:182), "Leverage yang disesuaikan akan naik atau turun dan dengan demikian akan menemukan apakah Return on Equity akan naik atau turun.

Penggunaan financial leverage yang semakin besar membawa dampak positif bila pendapatan yang diterima dari penggunaan dana tersebut lebih besar daripada bebannya keuangan yang dikeluarkan. Sedangkan dampak negatifnya penggunaan financial leverage yang semakin besar akan menyebabkan hutang semakin besar yang ditanggung perusahaan, yaitu beban tetap atau beban bunganya. Apabila perusahaan tidak memenuhi kewajibannya yang berupa beban bunganya, maka perusahaan akan mengalami kesulitan untuk menjalankan kegiatan usahanya.

\section{Pengaruh Debt to Equity Ratio secara Parsial terhadap Profitabilitas (Return on Equity) pada Perusahaan Makanan dan Minuman yang terdaftar di Bursa Efek Indonesia periode 2010-2014}

Hasil pengujian hipotesis parsial menunjukkan nilai t-stat untuk variabel Debt to Equity Ratio diperoleh sebesar 2,344 dengan nilai probabilitas sebesar 0,0234 . Nilai $t$-stat yang diperoleh lebih besar dari nilai t-tabel sehingga keputusan dalam pengujian hipotesis adalah menerima $\mathrm{H}_{1}$. Kesimpulan tersebut didukung pula dengan nilai probabilitas sebesar 0,0234 yang berarti lebih kecil dari nilai $\alpha=0,05$. Jadi, dapat disimpulkan bahwa pada tingkat signifikansi $95 \%$ Debt to Equity Ratio berpengaruh terhadap profitabilitas (Return on Equity) pada perusahaan sub sektor makanan dan minuman yang terdaftar di Bursa Efek Indonesia periode 2010-2014.

Sementara nilai koefisien regresi atas variabel Debt to Equity Ratio diperoleh nilai sebesar 13,210. Hal ini menunjukkan bahwa Debt to Equity Ratio memiliki pengaruh positif terhadap profitabilitas (Return on Equity). Pengaruh positif ini berarti, ketika nilai Debt to Equity Ratio meningkat satu satuan, maka rasio profitabilitas (Return on Equity) akan meningkat pula sebesar 13,210 satuan. Jadi, semakin tinggi proporsi hutang atas ekuitas pemegang saham maka akan semakin tinggi tingkat pengembalian laba yang didapat perusahaan. Hasil peneliitian ini sejalan dengan teori yang dikemukakan oleh Brigham dan Houston yang diterjemahkan oleh Ali Akbar Yulianto (2010:140), jika hasil yang diperoleh dari laba perusahaan lebih tinggi dari bunga pinjaman yang harus dibayarkan, maka penggunaan hutang akan 'mengungkit' (leverage) atau memperbesar pengembalian atas ekuitas atau ROE.

\section{SIMPULAN}

Peneliti dapat mengambil beberapa kesimpulan sebagai jawaban dari rumusan masalah yang menjadi acuan penelitian, antara lain sebagai berikut:

1. Financial leverage yang terdiri dari Debt Ratio dan Debt to Equity Ratio secara simultan berpengaruh terhadap profitabilitas (Return on Equity) pada perusahaan sub sektor makanan dan minuman yang tercatat di Bursa Efek Indonesia periode 2010-2014. Debt Ratio dan Debt to Equity Ratio secara simultan memberikan kontribusi atau pengaruh sebesar $87,4 \%$ terhadap Return on Equity.

2. Debt Ratio memiliki koefisien bertanda negatif, menunjukkan bahwa semakin tinggi nilai Debt Ratio akan menurunkan nilai Return on Equity. Hasil pengujian menunjukkan bahwa Debt Ratio berpengaruh negatif secara signifikan terhadap profitabilitas (Return on Equity) pada perusahaan sub sektor makanan dan 
minuman yang tercatat di Bursa Efek Indonesia periode 2010-2014.

3. Debt to Equity Ratio memiliki koefisien bertanda positif, menunjukkan bahwa semakin tinggi nilai Debt to Equity Ratio akan meningkatkan nilai Return on Equity. Hasil pengujian menunjukkan bahwa Debt to Equity Ratio berpengaruh positif secara signifkan terhadap profitabilitas (Return on Equity) pada perusahaan sub sektor makanan dan minuman yang tercatat di Bursa Efek Indonesia periode 2010-2014.

\section{DAFTAR PUSTAKA}

Ajija, Shochrul R et al. 2011. Cara Cerdas Menguasai Eviews. Salemba Empat: Jakarta.

Arthur J. Keown, David F. Scott, Jr., John D. Martin, J. William Petty. 2001. Dasar-dasar Manajemen Keuangan Edisi Ketujuh. Jakarta: Salemba Empat

Brigham, Eugene F dan Houston, Joel. 2010. Dasar-dasar Manajemen Keuangan Edisi 11 Buku I. Jakarta: Salemba Empat.

Brigham, Eugene F dan Houston, Joel. 2010. Dasar-dasar Manajemen Keuangan Edisi 11 Buku II. Jakarta: Salemba Empat.

Gujarati, Damodar. 2012. Dasar-Dasar Ekonomentrika. Jakarta: Erlangga.

M. Hanafi, Mahmud dan Halim. (2003). Analisis Laporan Keuangan. Edisi Revisi. Yogyakarta:UPP AMP YKPN.

Hariyanto, Bambang. 2005. Sistem Manajemen Basis Data: Pemodelan, Perancangan, dan Terapannya. Bandung: Informatika.

James, C. Van Horne \& John M. Wachowicz. 2013. Prinsip-Prinsip Manajemen Keuangan Buku II. Jakarta: Salemba Empat.

Kasmir. 2014. Analisis Laporan Keuangan. Jakarta: Raja Grafindo.

Bank Mandiri. 2014. Jurnal Industry Update Bank Mandiri Volume 4

Nazir, Moh. 2009. Metode Penelitian. Jakarta: Ghalia Indonesia.

Riyanto, Bambang. 2008. Dasar-dasar Pembelanjaan Perusahaan. Edisi Keempat. Yogyakarta: BPFE.
Sartono, R Agus. 2012. Manajemen Keuangan (Teori dan Aplikasi). Yogyakarta: BPFE.

Sutrisno. 2012. Manajemen Keuangan. Yogyakarta: Ekonesia.

Sugiyono. 2013. Metode Penelitian Bisnis. Bandung: CV Alfa Beta.

Syamsuddin, Lukman. 2011. Manajemen Keuangan Perusahaan. Edisi Baru. Jakarta: Raja Grafindo.

Website :

Daftar Perusahaan Sub Sektor Makanan dan Minuman di BEI. Dari http://www.sahamok.com. Diakses pada 28 September 2015

Data Keuangan Perusahaan Sub Sektor Makanan dan Minuman di BEI. Dari http://www.idx.com. Diakses pada 28 September 2015

Kenaikan omzet penjualan perusahaan makanan dan minuman. Dari_http://foodreview.biz/. Diakses tanggal 8 Desember 2015.

Nilai investasi perusahaan makanan dan minuman. Dari

http://cnnindonesia.com/ekonomi/2014.

Diakses 30 September 2015

Ringkasan Perusahaan tercatat. Dari http://www.idx.com. Diakses pada 27 Desember 2015. 
